'Laboratorio de Neuroinmunología, Fundación Ciencia \& Vida. Santiago, Chile. 2Departamento de Inmunología Clínica y Reumatología, Facultad de Medicina, Pontificia Universidad Católica de Chile. Santiago, Chile.

${ }^{3}$ Departamento de Ciencias Biológicas, Facultad de Ciencias de la Vida, Universidad Andres Bello. Santiago, Chile.

Supporting Grants: INNOVA 12IDL2-16030 (to R.P.)

form "Corporación de Fomento de la Producción", FONDECYT-1170093 (to R.P.) and FONDECYT-3160383 (to

C.P.) from "Fondo Nacional

de Desarrollo Científico y

Tecnológico de Chile", FONIS-

SA10I20010 (to P.I.B.) from "Fondo Nacional de Investigación

y Desarrollo en Salud", and

PFB-16 (to R.P.) from "Comisión

Nacional de Investigación

Científica y Tecnológica de Chile (CONICYT)".

Los autores declaran no tener conflictos de interés

Recibido el 31 de agosto de 2017, aceptado el 20 de febrero de 2018.

Correspondence to: Rodrigo Pacheco Av. Zañartu 1482, Ñuñoa, Santiago, Chile.

ORCID: 0000-0001-8057-9806 Phone: +562-23672046

Fax: + 562-22372259 rpacheco@cienciavida.org rodrigo.pacheco@unab.cl;

Paula I. Burgos Diagonal Paraguay 362. Santiago, Chile. Phone + 562-23543078 pburgos@med.puc.cl

Material suplementario en versión digital de la Revista Médica de Chile en https://scielo.conicyt.cl

\section{Smoking promotes exacerbated inflammatory features in dendritic cells of Chilean rheumatoid arthritis patients}

\author{
CAROLINA PRADO ${ }^{1, \mathrm{a},}$, MIRENTXU IRURETAGOYENA ${ }^{2, \mathrm{a}, \mathrm{b}}$, \\ PAULA I. BURGOS ${ }^{2, a, b}$ RODRIGO PACHECO ${ }^{1,3, a}$
}

\title{
ABSTRACT
}

Background: The dual potential to promote tolerance or inflammation when facing self-antigens makes dendritic cells (DCs) fundamental players in autoimmunity. There is an association between smoking and DCs maturation in patients with rheumatoid arthritis (RA). However, ethnicity is a key factor in autoimmune disorders. Aim: To evaluate phenotypic and functional alterations of DCs obtained from Chilean patients with RA as compared to healthy controls (HC). In second term, to compare the inflammatory behaviour of DCs between smoker and non-smoker patients. Material and Methods: Monocyte-derived $D C$ s and T-cells were obtained from blood samples isolated from $30 \mathrm{HC}$ and 32 RA-patients, 14 of which were currently smokers and 18 non-smokers. Several maturation surface markers were evaluated in DCs, including HLA-DR, CD40, CD80, CD83 and CD86. Furthermore, autologous co-cultures of DCs and T-cells were carried out and then T-cell proliferation, and expansion of Th1, Th17 and Tregs were analysed. Results: Compared with HC, RA-patients displayed increased HLA-DR expression in DCs, which was manifested mainly in patients with moderate-to- high disease activity scores (DAS28). Furthermore, RA-patients presented a stronger Th17-expansion and a correlation between DAS28 and Th1-expansion. Both effects were mainly observed in patients in remission or with a low DAS28. Moreover, smoker RA-patients displayed enhanced HLA-DR and CD83 expression in DCs as well as an exacerbated Th17-expansion and a correlation between DAS28 and Th1-expansion. Conclusions: These findings suggest that smoking enhances the inflammatory behaviour of DCs and the consequent Th1 and Th17-mediated response in patients with RA

(Rev Med Chile 2018; 146: 150-159)

Key words: Arthritis; Autoimmunity; Dendritic Cells; Smoking; T-Lymphocytes.

\section{El tabaco exacerba características inflamatorias en células dendríticas de pacientes chilenos con artritis reumatoide}

Introducción: El potencial dual que poseen para promover tolerancia o inflamación ante antígenos propios, hace de las células dendríticas (CDs) actores fundamentales en el desarrollo de autoinmunidad. Existe una asociación 
entre fumar y la maduración de las CDs en pacientes con artritis reumatoide (AR). No obstante, la etnicidad es un factor clave a considerar en desórdenes autoinmunes. Objetivos: Comparar las alteraciones fenotípicas y funcionales de las CDs obtenidas desde pacientes Chilenos con AR y controles sanos (CS). Además, analizamos las diferencias en el comportamiento inflamatorio que existe entre las CDs obtenidas de pacientes fumadores y CS. Materiales y Métodos: Se obtuvieron CDs derivadas de monocitos y células $T$ desde muestras de sangre aisladas de 30 CS y 32 pacientes con AR, 14 de los cuales eran fumadores y 18 no fumadores. Se evaluaron marcadores de maduración en la superficie de las CDs: HLA-DR, CD40, CD80, CD83 y CD86. Además, se realizaron co-cultivos autólogos de células $T$ y CDs, analizando la proliferación de células $T$, y la expansión de células Th1, Th17 y Tregs. Resultados: En comparación con los CS, los pacientes AR mostraron un aumento de la expresión de HLA-DR en las CDs, principalmente en los individuos con DAS28 moderado-alto. Los pacientes con AR presentaron una mayor expansión de células Th17 y una correlación entre el DAS28 y la expansión de células Th1, ambos efectos manifestados principalmente en los individuos con un DAS28 bajo o en remisión. Además, los pacientes con AR fumadores mostraron un aumento en la expresión de HLA-DR y CD83 en las CDs y una expansión de células Th17 exacerbada así como una correlación entre el DAS28 y la expansión de células Th1. Conclusiones: Nuestros resultados sugieren que fumar favorece el comportamiento inflamatorio de las CDs y en consecuencia la inducción de respuestas mediadas por células Th1 y Th17 en los pacientes Chilenos con AR.

T o prevent autoimmune reactions, auto-reactive T-cells have to be eliminated or rendered tolerant, a process in which dendritic cells (DCs) play a fundamental role. In fact, constitutive depletion of DCs results in spontaneous fatal autoimmunity ${ }^{1}$. Moreover, during onset of autoimmunity DCs seem to be pivotal for priming of auto-reactive T-cells that have escaped of tolerance induction ${ }^{2}$. This dual potential of DCs promoting tolerance or inducing inflammation to auto-antigens, makes these cells fundamental players in the physiopathology of autoimmunity.

Evidence has shown that the duality of DCs functionality is defined by the expression of surface molecules and secreted mediators. In this regard, the mild expression of surface class II MHC (MHC-II), CD40, CD83 and of the co-stimulatory molecules CD80 and CD86 is associated with the tolerogenic potential, whilst high surface density of all these molecules is indicative of the inflammatory potential of $\mathrm{DCs}^{3}$. In addition, whereas tolerogenic DCs produce retinoic acid and the anti-inflammatory cytokine IL-10 that favour generation of regulatory T-cells (Tregs) with suppressive activity ${ }^{4,5}$, DCs with inflammatory potential produce IL-12 and IL-23, which are required respectively to the acquisition of the inflammatory phenotypes T-helper-1 (Th1) and Th17 by naïve $\mathrm{CD} 4^{+} \mathrm{T}^{-c^{2}} \mathrm{ll} \mathrm{s}^{6,7}$. Of note, previous evidence has shown that Th1 as well as Th17 cells

\footnotetext{
Abbreviations: American College of Rheumatology, ACR; cluster of differentiation $n, \mathrm{CD} n$; collagen-induced arthritis, CIA; cell-trace violet, CTV; class II MHC, MHC-II; CIA; C-reactive protein, CRP; cyanine 7, Cy7; dendritic cells, DCs; disease activity score 28, DAS28; disease-modifying antirheumatic drugs, DMARDs; erythrocyte sedimentation rate, ESR; Granulocyte-macrophage colony-stimulating factor, GM-CSF; Health Assessment Questionnaire, HAQ; healthy controls, HC; Human Leukocyte Antigen DR, HLA-DR; immature DCs, iDCs; interferon gamma, IFN- $\gamma$; interleukin $n$, IL- $n$; lipopolysaccharide, LPS; monoclonal antibody, mAb; Major Histocompatibility Complex, MHC; mature DCs, mDCs; nuclear factor kappa B, NF-kB; peripheral blood mononuclear cells, PBMC; phycoerythrin, PE; phorbol 12-myristate 13-acetate, PMA; regulatory T-cells, Tregs; Rheumatoid Arthritis, RA; rheumatoid factor, RF; staphylococcal enterotoxin A, SEA; T helper $n$, Th $n$; Visual Analog Scale, VAS.
} 
are the phenotypes of auto-reactive $\mathrm{CD} 4^{+} \mathrm{T}$-cells involved in autoimmunity, including rheumatoid arthritis (RA) and its mouse model, the collagen-induced-arthritis (CIA $)^{8,9}$. Indeed, due to that functional phenotype of DCs represent a key point of decision to promote tolerance or inflammation in response to specific antigens, the use of tolerogenic DCs loaded with auto-antigens as therapy for the treatment of RA is currently under clinical trials ${ }^{10,11}$.

Accumulating evidence suggests that RA develops in genetically predisposed individuals after exposure to environmental triggers. In this regard, it has been shown that polymorphisms of various genes codifying for molecules involved in immunity, such as MHC-II, inflammasome or inflammatory cytokines are differentially distributed depending on the ethnicity ${ }^{12-14}$. Thus, these findings suggest that different ethnicity should affect the immune system behaviour in response to conditions representing risk factors triggering autoimmunity.

Among the environmental risk factors for RA one of the most documented is tobacco, a factor that favours the citrullination of self-constituents, which represent a major source of auto-antigens in $\mathrm{RA}^{15,16}$. Importantly, some studies have suggested that smoking has an impact on the functionality of DCs and their capacity to induce Th1/Th17-mediated responses in RA-patients ${ }^{17-19}$. Moreover, previous data has shown that nicotine promotes the activation of NF- $\kappa B$, increasing the pro-inflammatory potential of antigen-presenting cells ${ }^{20,21}$.

Despite there are previous studies analysing how DCs phenotype is altered in Chilean RA-patients ${ }^{22}$, the impact of smoking in the phenotype of DCs in relation to the severity of disease manifestation in Chilean RA-patients has not been previously addressed. In this study, we evaluated how is the functional phenotype of DCs affected in Chilean RA-patients and how tobacco impacts in DCs functionality and disease manifestation in those patients.

\section{Materials and Methods}

\section{Subjects}

Thirty-two female RA-patients were included in the study, born in Chile with Chilean parents who met the 1987 or 2010 American College of Rheumatology (ACR) classification criteria for $\mathrm{RA}^{23,24}$. All were outpatients from one clinical network consisting in: University Hospital of the Pontificia Universidad Católica de Chile and San Joaquín Medical Center. Foreigners or patients with foreign parents, or those who had clinical overlap with other autoimmune diseases were excluded. Clinical description of our patients is shown in Table 1. Treatment of patients analysed included methotrexate with doses ranging between 10 and 25 mg weekly; prednisone with doses ranging between 0 and $20 \mathrm{mg}$ per day; sulfasalazine with doses ranging between 2,100 and $700 \mathrm{mg}$ daily; and hydroxychloroquine at a dose of $200 \mathrm{mg}$ daily. No patients under therapy with biological agents were included in this study. All patients who agreed to participate in this study signed an informed consent and, once recruited, we proceeded to obtain demographic and clinical data by questionnaire and assessment by coordinators and rheumatologists. Thirty healthy female with an average age of $42 \pm 13$ years were included as $\mathrm{HC}$,

\section{Table 1. Demographic features, disease activity and laboratory parameters in Female Rheumatoid Arthritis (RA) patients and Healthy Controls (HC)}

\begin{tabular}{|c|c|}
\hline & RA patients $(n=32)$ \\
\hline Age (years) & $50,00 \pm 12,63$ \\
\hline Current Smokers (+/-) & $14 / 18$ \\
\hline Disease Duration (years) & $6,03 \pm 5,54$ \\
\hline DAS28 (mean $\pm \mathrm{sd})$ & $4,03 \pm 1,88$ \\
\hline \multicolumn{2}{|l|}{ DAS28 Frequency } \\
\hline Remission, < 2,6 (n) & 8 \\
\hline Mild, $2,6<3,2$ (n) & 6 \\
\hline Moderate, $3,2<5,1$ (n) & 7 \\
\hline Severe, $>5,1(n)$ & 11 \\
\hline $\mathrm{ESR}^{1}(\mathrm{~mm} / 1 \mathrm{st} h)$ & $38,84 \pm 3,07$ \\
\hline $\mathrm{CRP}^{1}(\mathrm{mg} / \mathrm{dL})$ & $848,4 \pm 923,20$ \\
\hline $\mathrm{RF}^{1}(\mathrm{IU} / \mathrm{mL})$ & $387,8 \pm 773,3$ \\
\hline \multicolumn{2}{|l|}{ Treatment } \\
\hline Methotrexate (+/-) & $20 / 12$ \\
\hline Prednisone (+/-) & $14 / 18$ \\
\hline Azulfidine (+/-) & $08 / 24$ \\
\hline
\end{tabular}

'ESR: erythrocyte sedimentation rate, CRP: c-reactive protein, RF: rheumatoid factor. 
which were summoned to an interview in order to explain the study. The study was conducted over a period of 18 months and was approved by the local University Ethics Committee.

\section{Variables ascertained}

Data about comorbidities and previous/currents treatments was obtained in the interview and confirmed in their medical record. Serum samples were stored at $-80^{\circ} \mathrm{C}$ to complete study of antibodies. The ACR core of set of variables ${ }^{25}$ including the number of swollen joints, the number of painful joints (ascertained by study physicians) and a pain scale were recorded at the visit. Functional status was assessed with the Health Assessment Questionnaire (HAQ); the HAQ is scored on a scale of $0-3$, with higher scores indicating higher levels of disability ${ }^{26}$. The intensity of their pain was assessed with a $10 \mathrm{~cm}$ Visual Analog Scale (VAS) where 0 is no pain and 10 is the worst possible pain. The HAQ and VAS were self-administered during the patients' scheduled visits. Clinical data and disease duration were obtained, routine blood sample biochemistry, C-reactive protein (CRP) and erythrocyte sedimentation rate (ESR) were measured at the time of the study visit. These parameters also allowed calculating the score of disease activity (DAS28) ${ }^{27}$. Activity was classified as remission (DAS28 <2.6), low-activity $(2.6 \leq \mathrm{DA} 28$ $\leq 3.2)$, moderate-activity $(3.2<$ DAS $28 \leq 5.1)$ and high-activity (DAS28 $>5.1$ ). To define 2 groups, we merge remission with low activity and moderate with high activity. Exposure to DMARDs was defined as more than 3-months of use of them without modifications. Methotrexate, glucocorticoids, hydroxychloroquine, cyclophosphamide, azathioprine, mycophenolate mophetil were also recorded. Tobacco was recorded as present or absent in the last 3-months. The laboratory data evaluated the presence of rheumatoid factor (RF) and anti-CCP by immunoturbidimetry and ELI$\mathrm{SA}$, respectively.

\section{Antibodies}

All fluorochrome-conjugated monoclonal antibodies (mAbs) were purchased from Biolegend (San Diego, CA), including PE-anti-CD11c, allophycocyanin-anti-CD14, allophycocyanin-Cy7-anti-HLA-DR, PE-Cy7-anti-CD40, Brilliant-Violet421-anti-CD80, Alexa-Fluor488-antiCD83, allophycocyanin-anti-CD86, Brilliant-Vio-
let421-anti-CD3, allophycocyanin-anti-CD4, PerCP-anti-CD25, Alexa-Fluor647-anti-FoxP3, Brilliant-Violet510-anti-IFN- $\gamma$, allophycocyanin-Cy7-anti-IL-17, allophycocyanin-anti-Tbet, PE-anti-GM-CSF.

\section{Generation of Monocyte-Derived DCs and autologous co-cultures}

Monocyte-derived DCs were differentiated as described ${ }^{28}$. DCs immunophenotypes were analysed by flow cytometry as indicated in Figure S1. Autologous co-cultures were carried out with DCs (purity $88 \% \leq \mathrm{CD} 11 \mathrm{c}^{+}$) and with the T-cell enriched fraction obtained from non-adherent PBMCs, as described before ${ }^{29}$, and analysed as indicated in Figure S2.

\section{Flow cytometry analyses}

For immunostaining of cell-surface markers, cells were washed with PBS, resuspended at $2 \times 10^{6}$ cells/ml ( $50 \mu \mathrm{l} /$ tube), stained with the ZombieAqua (Fixable-Viability kit, Biolegend) and incubated with fluorochrome-conjugated mAbs for 30 $\min$ at $4{ }^{\circ} \mathrm{C}$. Cells were washed with PBS, fixed with $1 \%$ formaldehyde in PBS and analysed by flow cytometry. To analyse expression of transcription factors and production of cytokines, cells were restimulated with $1 \mu \mathrm{g} / \mathrm{mL}$ ionomycin and $50 \mathrm{ng} / \mathrm{mL}$ PMA for $4 \mathrm{~h}$ in the presence of $5 \mu \mathrm{g} / \mathrm{mL}$ brefeldin A. Cells were stained with ZombieAqua, followed by staining for cell-surface markers. Intracellular staining was done with the Intracellular Fixation and Permeabilization Buffer Set (eBioscience, San Diego, CA). Data were collected with a Canto II (BD) and analysed in the ZombieAqua-negative population using the FlowJo software (Tree Star).

\section{Statistical analysis}

All values were expressed as mean \pm SEM. Differences in means between two groups were analysed by 2-tailed Student's $t$-test. When three or more experimental groups were compared, differences were analysed by one-way ANOVA followed by Dunnett's post-hoc test. Correlations between different parameters were analysed by Pearson's test when data was normally distributed or by Spearman's test when data was not normally distributed. Normal distribution was determined by Shapiro-Wilk test. $P$ value $\leq 0.05$ was considered significant. Analyses were performed with GraphPad Prism 6 software. 


\section{Results}

\section{DCs obtained from Chilean RA-patients display increased inflammatory features}

To evaluate whether the functional phenotype of DCs is altered in RA-patients with respect to $\mathrm{HC}$ we aimed to compare key surface markers involved in the functional switch from tolerogenic to inflammatory DCs. For this purpose monocyte-derived DCs were generated and a pool of key surface maturation markers were analysed by flow cytometry in the $\mathrm{CD} 11 \mathrm{c}^{+}$population, including HLA-DR, CD40, CD80, CD83 and CD86. The results show a selective increase in the surface density of HLA-DR on DCs obtained from RA-patients in comparison with those DCs obtained from HC, whilst there were no significant alterations on the other surface markers analysed (Figure 1A). In addition of surface markers we also analysed the functionality of DCs with regard to their capability to stimulate inflammatory or anti-inflammatory $\mathrm{CD}^{+} \mathrm{T}$-cell responses. Accordingly, we performed a set of co-culture experiments in which DCs were loaded with a superantigen (staphylococcal enterotoxin A; SEA), cultured with autologous $\mathrm{T}$-cells and then the general proliferation or the expansion of the suppressive subset Tregs, and inflammatory populations, including Thl and Th17, were analysed. Interestingly, when correlation analyses were performed (Table S1), a significant association between disease severity (DAS28) and the expansion of Th1 cells $\left(\mathrm{CD}^{+} \mathrm{CD}^{+}\right.$Tbet $^{+}$cells) in co-cultures was found (Figure 1B). Furthermore, whereas the general proliferation (Figure 1C), expansion of Tregs (Figure 1D) or expansion of Th1 (Figure 1E) were unaltered, the generation of Th17 was significantly increased in co-cultures obtained from RA-patients in comparison to those obtained from HC (Figure 1F). Together, these results indicate that DCs obtained from Chilean RA-patients display an increased ability to promote an inflammatory $\mathrm{CD}^{+}{ }^{+} \mathrm{T}$-cell response.

\section{Disease activity is not completely associated to the exacerbated inflammatory features of DCs obtained from RA-patients}

To gain a deeper characterization of which are the subtypes of RA-patients displaying alterations in the phenotype and function of DCs, we next analysed the key surface maturation markers and the capability to promote expansion of diffe- rent T-cell subsets on DCs obtained from those RA-patients displaying moderate-to-high-DAS28 (DAS28 $>3.2 ; 18$ patients) and from those bearing remission or low-DAS28 (DAS28 $<3.2 ; 14$ patients) in comparison to DCs obtained from HC. These results show that DCs obtained from moderate-to-high-DAS28 RA-patients display a selectively exacerbated up-regulation of surface HLA-DR in comparison to those DCs obtained from HC (Figure 2A). However, unexpectedly the increased capability of DCs to promote expansion of Th17 cells was confined to those DCs obtained from the subgroup of RA-patients displaying remission or low-DAS28 (Figure 2B). Similarly, positive correlations were observed between disease severity and the capability to promote expansion of Th1 cells (analysed as $\mathrm{CD}^{+}{ }^{+} \mathrm{CD} 4^{+} \mathrm{Tbet}^{+}$or $\mathrm{CD} 3^{+} \mathrm{CD} 4^{+} \mathrm{Tbe}-$ $\mathrm{t}^{+}$IFN- $\gamma^{+}$populations) exclusively in DCs obtained from remission or low-DAS28 RA-patients (Figure $2 \mathrm{C}$ and Table S1). Taken together, these results indicate that exacerbated inflammatory features observed in Chilean RA-patients are not clearly associated to the disease severity. Thereby, these findings suggest that other parameters different to disease severity should be related to the higher inflammatory potential of DCs obtained from RA-patients.

\section{Selective increase of inflammatory features of DCs obtained from smoker RA-patients}

Since smoking has been associated to the alteration of inflammatory parameters in antigen-presenting cells obtained from RA-patients with other ethnicities ${ }^{17,30}$, we next analysed whether the alterations observed in the inflammatory potential of DCs observed in Chilean RA-patients (Figure 1) were also related with this environmental risk factor. When we compared the extent of expression of surface maturation markers and the parameters determined in co-culture experiments between the subgroups of smoker RA-patients and non-smoker RA-patients we did not find significant differences (data not shown). However, co-cultures obtained from smokers RA-patients revealed an exacerbated expansion of Th17 cells with an evident trend $(\mathrm{p}=0,0612)$ in comparison to those co-cultures obtained from non-smokers RA-patients (Figure $3 \mathrm{~A})$. In agreement with this observation, when the inflammatory features of DCs were compared between $\mathrm{HC}$ and the subgroup of smoker RA-pa- 
A

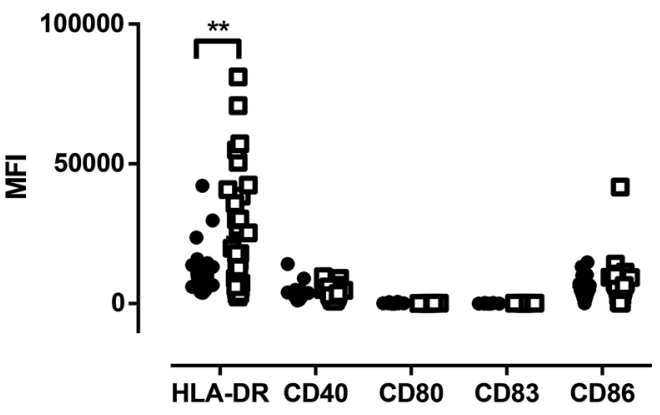

B

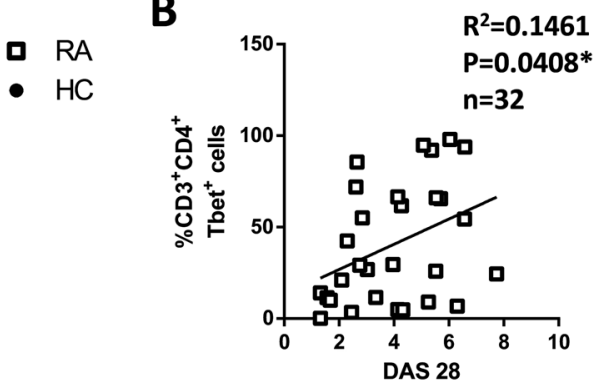

C

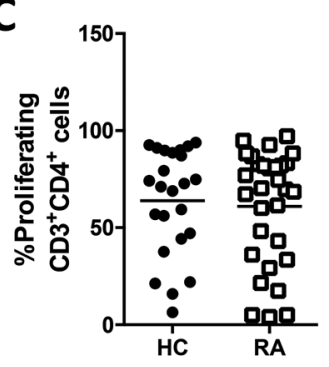

D

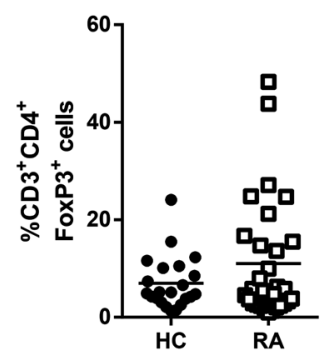

E
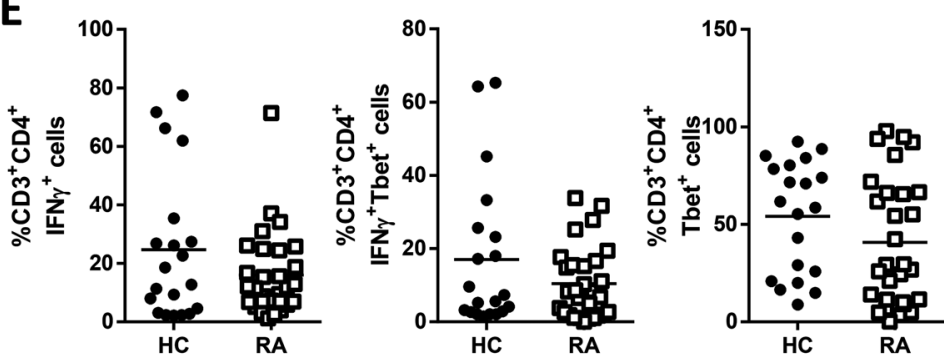

$\mathbf{F}$

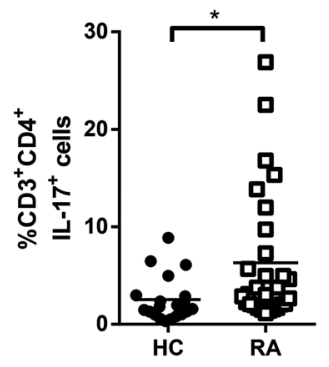

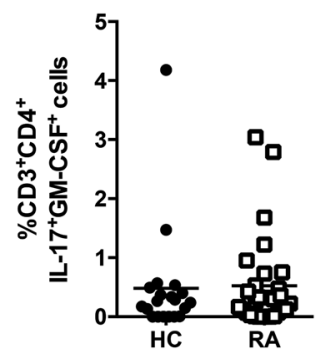

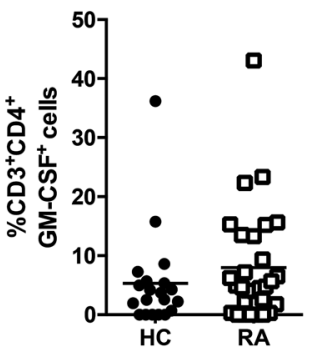

Figure 1. DCs obtained from RA patients display a selective up-regulation of HLA-DR on the cell surface and increased capacity to promote inflammatory phenotypes in CD4+ T-cells. Monocyte-derived DCs were obtained from peripheral blood from healthy control (HC) or Rheumatoid Arthritis (RA) patients. After 6 days of culture in presence of GM-CSF and IL-4, we determined the expression of several maturation markers by flow cytometry. (A) The surface density of maturation markers was quantified as the MFI of the marker confined to the CD11 $\mathrm{C}^{+} \mathrm{DCs}$ population. (B-F) DCs obtained from HC or RA patients were pulsed with staphylococcus aureus enterotoxin A (SEA) $1 \mathrm{ng} / \mathrm{mL}$ for $1 \mathrm{~h}$. Then DCs were washed and co-culture with autologous T-cells at 1:5 ratio for 7 days. (B) The correlation between DAS28 from all patients and Tbe$\mathrm{t}^{+} \mathrm{CD} 3^{+} \mathrm{CD} 4{ }^{+}$cells frequency was analysed. (C) Dilution of Cell trace Violet (CTV) fluorescence was assessed in the $\mathrm{CD} 3^{+} \mathrm{CD} 4{ }^{+}$ population by FACS. (D) Tregs generation was determined by expression of FoxP3, (E) Th1 polarization was determined by Tbet and IFN- $\gamma$ expression and (F) Th17 polarization was determined by expression of GM-CSF and IL-17 in the CD3 ${ }^{+}$CD4 ${ }^{+}$ population. Values represent mean \pm SEM, with 32 RA patients (grey symbols) and $30 \mathrm{HC}$ (black symbols). Data was analysed by One-way ANOVA followed by Dunnett's multiple comparison post-hoc test (A), Spearman's correlation analysis (B) and Student's t-Test (C-F).* ${ }^{*} p<0,05 ;{ }^{* *}, p<0,01$. 


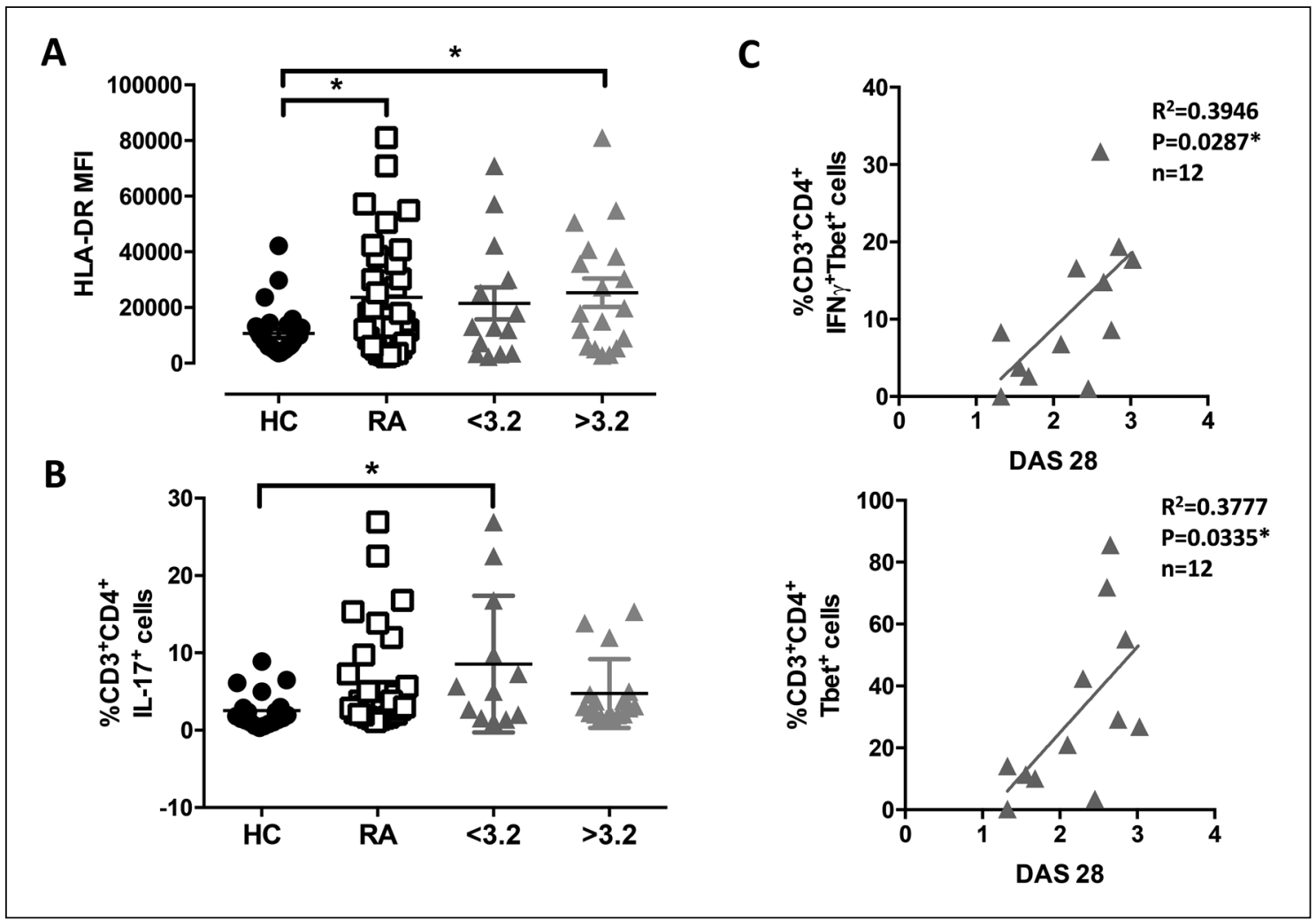

Figure 2. Up-regulation of HLA-DR in DCs from RA patients is explained by high-DAS28 patients, whilst increased capacity to promote inflammatory phenotypes in CD4+ T-cells is confined to low-DAS28 patients. Monocyte-derived DCS and autologous co-cultures of DCs with T-cells were obtained from peripheral blood from healthy control (HC) or Rheumatoid Arthritis (RA) patients as described in figure 1 legend. Data was analysed in a sub-group of RA patients with DAS28 lower than 3.2 ( $<3.2$, grey triangles) and higher than $3.2(>3.2$, black triangles) and compared with total RA patients and HC. (A) The surface density of HLA-DR was quantified as the MFI of the marker confined to the CD11 $\mathrm{C}^{+}$ DCs population. (B) Th17 polarization was determined by the expression of IL-17 in the $\mathrm{CD} 3^{+} \mathrm{CD} 4^{+}$population. (C) The correlation between DAS28 from low-DAS28 patients and Th1 cells was analysed as the frequency of $\mathrm{Tbet}^{+} \mathrm{CD} 3^{+} \mathrm{CD} 4^{+} \mathrm{IFN}-\gamma^{+}$ cells (top panel) or Tbet $^{+} \mathrm{CD} 3^{+} \mathrm{CD} 4^{+}$cells (bottom panel). Values represent mean \pm SEM, with 32 RA patients (grey squares), 14 low-DAS28 RA patients (light grey triangles), 18 high-DAS28 RA patients (dark grey triangles) and 30 HC (black symbols). Data was analysed by One-way ANOVA followed by Dunnett's multiple comparison post-hoc test (A and B) and Spearman's correlation analysis (C). ${ }^{*}, p<0,05$.

tients, we found a significant increased expansion of Th17 response (Figure 3B) and exacerbated surface density of the maturation markers HLADR and CD83 (Figure 3C-D). No differences were found when the other surface maturation markers and parameters determined in co-culture experiments were analysed (data not shown). Interestingly, when maturation surface markers were compared in $\mathrm{HC}$ and RA-patients in iDCs and mDCs, we observed that HLA-DR density was exacerbated in both smoker and non-smoker RA-patients in iDCs, whilst after DCs maturation exacerbated HLA-DR density was maintained only in smoker RA-patients (Figure S3). It is noteworthy that after DCs maturation CD86 density becomes increased in both smoker and non-smoker RA-patients (Figure S3). Furthermore, we analysed the association of clinical score with the different parameters associated to the inflammatory potential of DCs in the subgroup of smoker RA-patients and we found a significant correlation of DAS28 with the induction of Th1 cells in autologous co-cultures (Figure $3 \mathrm{E})$. To rule out the possibility that exacerbated 


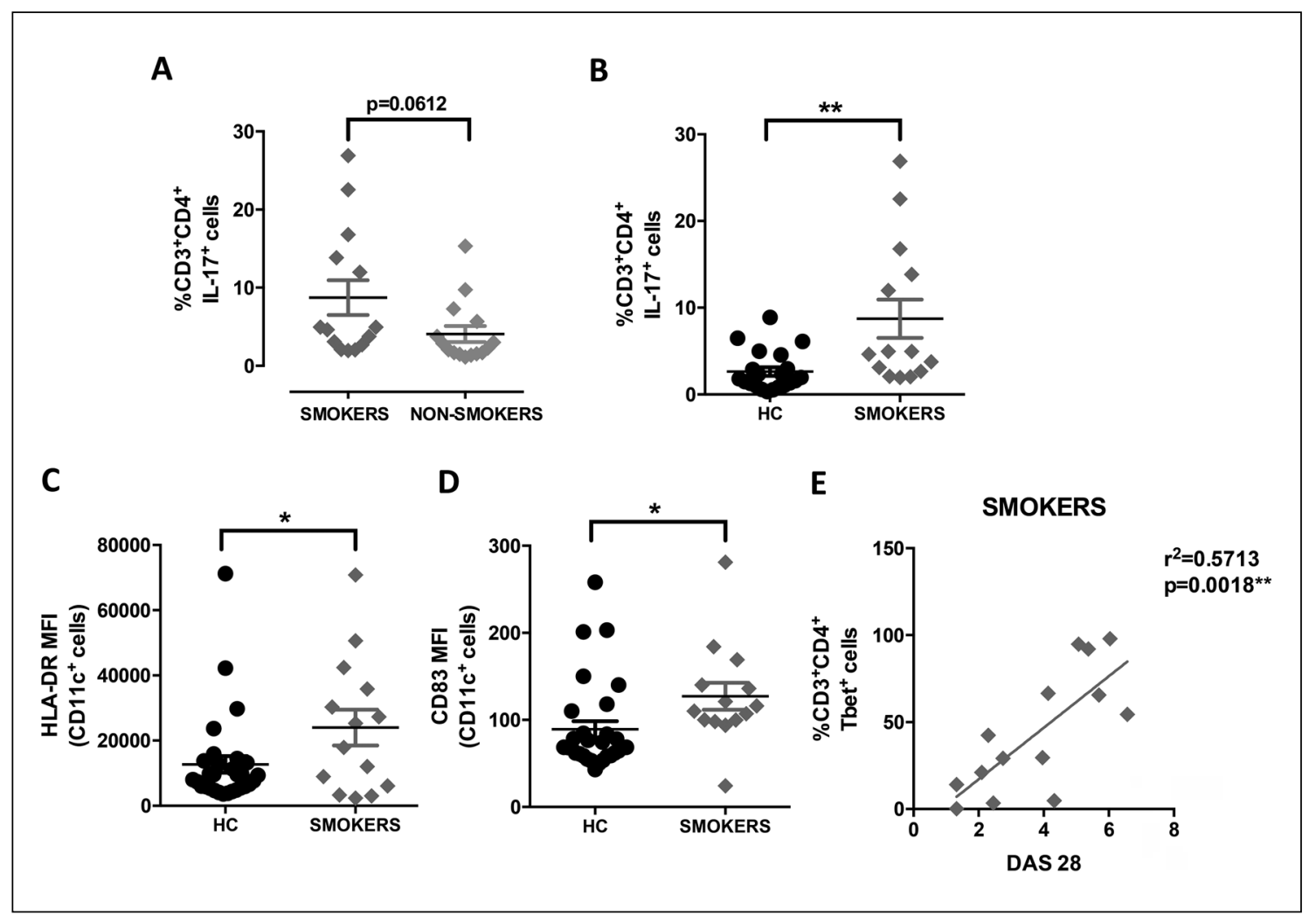

Figure 3. Selective increase in surface maturation markers in DCs and in the frequency of Th17 cells induced in autologous DC-T co-cultures obtained from smoker-RA patients. Monocyte-derived DCs and autologous co-cultures of DCs with T-cells were obtained from peripheral blood from healthy controls (HC) and Rheumatoid Arthritis (RA) patients as described in figure 1 legend. Data was analysed in the sub-group of smoker (+) or non-smoker (-) RA patients. (A) Th17 polarization was determined by the expression of $\mathrm{IL}-17$ in the $\mathrm{CD} 3^{+} \mathrm{CD} 4^{+}$population in co-cultures obtained from smoker or non-smoker RA patients. (B)Th17 polarization was determined by the expression of IL-17 in the $\mathrm{CD}^{+}{ }^{+} \mathrm{CD} 4{ }^{+}$population in co-cultures obtained from $\mathrm{HC}$ or from the sub-group of smoker-RA patients. (C-D) The surface density of HLA-DR $(\mathbf{C})$ and CD83 (D) was quantified as the MFI of the marker confined to the CD11 $\mathrm{C}^{+}$DCs population in $\mathrm{HC}$ and smoker-RA patients. Values represent mean \pm SEM, with 14 smoker-RA patients (open squares), 18 non-smoker RA patients (grey squares) and $30 \mathrm{HC}$ (black circles). (E) The correlation between DAS28 from smoker RA patients and Tbet ${ }^{+} \mathrm{CD} 3^{+} \mathrm{CD}^{+}$cells frequency. Data was analysed by Student's $t$-Test (A-D) or Spearman's correlation analysis (E). ${ }^{*} p<0,05 ;{ }^{* *}, p<001$.

inflammatory parameters observed in T-cells in co-culture experiments were due to alterations in CD4+ T-cells rather than DCs, we analysed how were the phenotypes of CD4+ T-cells obtained from fresh peripheral blood of RA-patients. The results show no significant differences in the frequencies of inflammatory and suppressive phenotypes of CD4+ T-cells among HC, smoker and non-smoker RA-patients (Figure S4). Thus, these results indicate that tobacco favours the exacerbation of the inflammatory potential of DCs in several aspects in Chilean RA-patients.

\section{Discussion}

This study shows a selective effect of tobacco favouring the inflammatory features of DCs in Chilean RA-patients. Of note, this is the first work analysing how smoking impacts on the inflammatory behaviour of DCs in a group of Chilean RA-patients.

Despite a recent study has shown no differences in HLA-DR expression in DCs obtained from Chilean RA-patients and $\mathrm{HC}^{22}$, our data here shows a strong exacerbation of HLA-DR density 
in DCs obtained from Chilean RA-patients in comparison to Chilean HC (Figure 1A). This discrepancy could be due to the different sources of monocytes obtained to be differentiated into DCs: Whereas García-González obtained monocytes from leukopheresis from RA-patients and from buffy-coats from $\mathrm{HC}^{22}$, here we obtained monocytes from fresh blood samples from RA-patients and HC. Since smoke has been proposed to represent one of the main environmental factors exacerbating disease manifestations and triggering RA ${ }^{15,16}$, we decided to analyse our results confined to the subgroup of smoker and non-smoker RA-patients. Despite smoker and non-smoker RA-patients present similar socio-demographic and clinical features (Table S2), we found that cigarette significantly favours an inflammatory phenotype on monocyte-derived DCs with a consequent increase in Th17 response in Chilean RA-patients (Figure 3). In contrast, a previous study addressing the link between smoke and the inflammatory potential of DCs found that cigarette reduced the production of IL- 6 by monocyte-derived DCs, which was associated to a decreased Th17 response in New Zealander RA-patients ${ }^{17}$. Discrepancies obtained between this study and our present results might be due to different ethnicity of RA-patients in both studies, a key factor conditioning the response of immune system to environmental factors ${ }^{12-14}$. Supporting this hypothesis, a recent study performed in transgenic mice lacking endogenous MHC-II and bearing the human RA-associated alleles HLADRB ${ }^{\star} 0401$ or DQA $1^{\star} 0301 / \mathrm{DQB} 1{ }^{\star} 0302$ showed that exposition of HLA-DRB $1^{\star} 0401$-bearing mice to cigarette smoke reduces CIA severity, whilst DQA $1^{\star} 0301 / \mathrm{DQB} 1^{\star} 0302$-bearing mice exposed to cigarette smoke exacerbated CIA manifestation $^{30}$. Studies in Chilean RA-patients show high frequency of the HLA-DRB ${ }^{\star} 0403$ allele ${ }^{31}$, which could account for the differences observed.

Material suplementario en versión digital de la Revista Médica de Chile en https://scielo.conicyt.cl

Acknowledgements: We thank Rebeca Montalva for her assistance in the extraction of blood samples.

\section{References}

1. Ohnmacht C, Pullner A, King SB, Drexler I, Meier S,
Brocker T, et al. Constitutive ablation of dendritic cells breaks self-tolerance of CD4 T cells and results in spontaneous fatal autoimmunity. J Exp Med 2009; 206 (3): 549-59.

2. Yoshida Y, Yoshimi R, Yoshii H, Kim D, Dey A, Xiong $\mathrm{H}$, et al. The transcription factor IRF8 activates integrin-mediated TGF-beta signaling and promotes neuroinflammation. Immunity 2014; 40 (2): 187-98.

3. Torres-Aguilar H, Aguilar-Ruiz SR, González-Pérez G, Munguia R, Bajana S, Meraz-Ríos MA, et al. Tolerogenic dendritic cells generated with different immunosuppressive cytokines induce antigen-specific anergy and regulatory properties in memory CD4+ T cells. J Immunol 2010; 184 (4): 1765-75.

4. Sun CM, Hall JA, Blank RB, Bouladoux N, Oukka M, Mora JR, et al. Small intestine lamina propria dendritic cells promote de novo generation of Foxp3 T reg cells via retinoic acid. J Exp Med 2007; 204 (8): 1775-85.

5. Park MJ, Min SY, Park KS, Cho YG, Cho ML, Jung YO, et al. Indoleamine 2,3-dioxygenase-expressing dendritic cells are involved in the generation of CD4+CD25+ regulatory T cells in Peyer's patches in an orally tolerized, collagen-induced arthritis mouse model. Arthritis Res Ther 2008; 10 (1): R11.

6. Wagner AH, Conzelmann M, Fitzer F, Giese T, Gulow $\mathrm{K}$, Falk CS, et al. JAK1/STAT3 activation directly inhibits IL-12 production in dendritic cells by preventing $\mathrm{CDK} 9 / \mathrm{P}-\mathrm{TEFb}$ recruitment to the p35 promoter. Biochem Pharmacol 2015; 96 (1): 52-64.

7. Hoentjen F, Sartor RB, Ozaki M, Jobin C. STAT3 regulates NF-kappaB recruitment to the IL-12p40 promoter in dendritic cells. Blood 2005; 105 (2): 689-96.

8. Liu C, Jiang J, Gao L, Wang X, Hu X, Wu M, et al. Soluble PD-1 aggravates progression of collagen-induced arthritis through Th1 and Th17 pathways. Arthritis Res Ther 2015; 17: 340.

9. Niu X, Deng S, Li S, Xi Y, Li C, Wang L, et al. Therapeutic effect of ergotope peptides on CIA by down-regulation of inflammatory and Th1/Th17 responses and induction of regulatory T cells. Mol Med 2016; 22.

10. Bell GM, Anderson AE, Diboll J, Reece R, Eltherington O, Harry RA, et al. Autologous tolerogenic dendritic cells for rheumatoid and inflammatory arthritis. Ann Rheum Dis 2017; 76 (1): 227-34.

11. Benham H, Nel HJ, Law SC, Mehdi AM, Street S, Ramnoruth N, et al. Citrullinated peptide dendritic cell immunotherapy in HLA risk genotype-positive rheumatoid arthritis patients. Science translational medicine 2015; 7 (290): 290ra87.

12. Kim SK, Choe JY, Bae J, Chae SC, Park DJ, Kwak SG, et al. TNFAIP3 gene polymorphisms associated with 
differential susceptibility to rheumatoid arthritis and systemic lupus erythematosus in the Korean population. Rheumatology (Oxford) 2014; 53 (6): 1009-13.

13. Sui J, Li H, Fang Y, Liu Y, Li M, Zhong B, et al. NLRP1 gene polymorphism influences gene transcription and is a risk factor for rheumatoid arthritis in han chinese. Arthritis Rheum 2012; 64 (3): 647-54.

14. Barnetche T, Constantin A, Cantagrel A, Cambon-Thomsen A, Gourraud PA. New classification of HLA-DRB1 alleles in rheumatoid arthritis susceptibility: a combined analysis of worldwide samples. Arthritis Res Ther 2008; 10 (1): R26.

15. Quirke AM, Fisher BA, Kinloch AJ, Venables PJ. Citrullination of autoantigens: upstream of TNFalpha in the pathogenesis of rheumatoid arthritis. FEBS letters 2011; 585 (23): 3681-8.

16. Boissier MC, Semerano L, Challal S, Saidenberg-Kermanac'h N, Falgarone G. Rheumatoid arthritis: from autoimmunity to synovitis and joint destruction. J Autoimmun 2012; 39 (3): 222-8.

17. Kazantseva MG, Highton J, Stamp LK, Hessian PA. Dendritic cells provide a potential link between smoking and inflammation in rheumatoid arthritis. Arthritis Res Ther 2012; 14 (5): R208.

18. Lutzky V, Hannawi S, Thomas R. Cells of the synovium in rheumatoid arthritis. Dendritic cells. Arthritis Res Ther 2007; 9 (4): 219.

19. Yu H, Yang YH, Rajaiah R, Moudgil KD. Nicotine-induced differential modulation of autoimmune arthritis in the Lewis rat involves changes in interleukin-17 and anti-cyclic citrullinated peptide antibodies. Arthritis Rheum 2011; 63 (4): 981-91.

20. Lau PP, Li L, Merched AJ, Zhang AL, Ko KW, Chan L. Nicotine induces proinflammatory responses in macrophages and the aorta leading to acceleration of atherosclerosis in low-density lipoprotein receptor(-/-) mice. Arteriosclerosis, thrombosis, and vascular biology 2006; 26 (1): 143-9.

21. Ueno H, Pradhan S, Schlessel D, Hirasawa H, Sumpio BE. Nicotine enhances human vascular endothelial cell expression of ICAM-1 and VCAM-1 via protein kinase C, p38 mitogen-activated protein kinase, NF-kappaB, and AP-1. Cardiovascular toxicology 2006; 6 (1): 39-50.

22. García-González PA, Schinnerling K, Sepúlveda-Gutiérrez A, Maggi J, Hoyos L, Morales RA, et al. Treatment with Dexamethasone and Monophosphoryl Lipid A Removes Disease-Associated Transcriptional Signatures in Monocyte-Derived Dendritic Cells from Rheumatoid Arthritis Patients and Confers Tolerogenic Features. Frontiers in immunology 2016; 7: 458.

23. Aletaha D, Neogi T, Silman AJ, Funovits J, Felson DT, Bingham CO, 3rd, et al. 2010 rheumatoid arthritis classification criteria: an American College of Rheumatology/European League Against Rheumatism collaborative initiative. Ann Rheum Dis 2010; 69 (9): 1580-8.

24. Arnett FC, Edworthy SM, Bloch DA, McShane DJ, Fries JF, Cooper NS, et al. The American Rheumatism Association 1987 revised criteria for the classification of rheumatoid arthritis. Arthritis Rheum 1988; 31 (3): 315-24.

25. Felson DT, Anderson JJ, Boers M, Bombardier C, Chernoff M, Fried B, et al. The American College of Rheumatology preliminary core set of disease activity measures for rheumatoid arthritis clinical trials. The Committee on Outcome Measures in Rheumatoid Arthritis Clinical Trials. Arthritis Rheum 1993; 36 (6): 729-40.

26. Fries JF, Spitz P, Kraines RG, Holman HR. Measurement of patient outcome in arthritis. Arthritis Rheum 1980; 23 (2): 137-45.

27. Prevoo ML, van 't Hof MA, Kuper $H H$, van Leeuwen MA, van de Putte LB, van Riel PL. Modified disease activity scores that include twenty-eight-joint counts. Development and validation in a prospective longitudinal study of patients with rheumatoid arthritis. Arthritis Rheum 1995; 38 (1): 44-8.

28. Oliva H, Pacheco R, Martínez-Navio JM, Rodríguez-García M, Naranjo-Gómez M, Climent $\mathrm{N}$, et al. Increased expression with differential subcellular location of cytidine deaminase APOBEC3G in human CD4(+) T-cell activation and dendritic cell maturation. Immunol Cell Biol 2016; 94 (7): 689-700.

29. Pacheco R, Oliva H, Martínez-Navio JM, Climent N, Ciruela F, Gatell JM, et al. Glutamate released by dendritic cells as a novel modulator of T cell activation. J Immunol 2006; 177 (10): 6695-704.

30. Vassallo R, Luckey D, Behrens M, Madden B, Luthra $\mathrm{H}$, David C, et al. Cellular and humoral immunity in arthritis are profoundly influenced by the interaction between cigarette smoke effects and host HLA-DR and DQ genes. Clin Immunol 2014; 152 (1-2): 25-35.

31. González A, Nicovani S, Massardo L, Aguirre V, Cervilla $\mathrm{V}$, Lanchbury JS, et al. Influence of the HLA-DR beta shared epitope on susceptibility to and clinical expression of rheumatoid arthritis in Chilean patients. Ann Rheum Dis 1997; 56 (3): 191-3. 